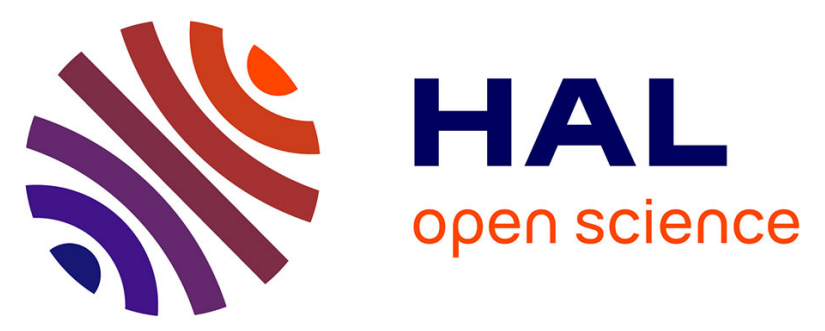

\title{
Plant-dominated assemblage and invertebrates from the lower Cenomanian of Jaunay-Clan, western France
}

Xavier Valentin, Bernard Gomez, Véronique Daviero-Gomez, Sylvain Charbonnier, Patrice Ferchaud, Alexander Kirejtshuk, Alexis Licht, Didier Néraudeau, Romain Vullo, Géraldine Garcia

\section{To cite this version:}

Xavier Valentin, Bernard Gomez, Véronique Daviero-Gomez, Sylvain Charbonnier, Patrice Ferchaud, et al.. Plant-dominated assemblage and invertebrates from the lower Cenomanian of Jaunay-Clan, western France. Comptes Rendus. Palevol, 2014, 13 (5), pp.443-454. 10.1016/j.crpv.2014.04.001. insu-01017379

\section{HAL Id: insu-01017379 \\ https://hal-insu.archives-ouvertes.fr/insu-01017379}

Submitted on 2 Jul 2014

HAL is a multi-disciplinary open access archive for the deposit and dissemination of scientific research documents, whether they are published or not. The documents may come from teaching and research institutions in France or abroad, or from public or private research centers.
L'archive ouverte pluridisciplinaire HAL, est destinée au dépôt et à la diffusion de documents scientifiques de niveau recherche, publiés ou non, émanant des établissements d'enseignement et de recherche français ou étrangers, des laboratoires publics ou privés. 


\title{
Plant-dominated assemblage and invertebrates from the lower Cenomanian of Jaunay-Clän, western France
}

\author{
Association de plantes et d'invertébrés dans le Cénomanien inférieur de Jaunay- \\ Clan, ouest de la France
}

Xavier Valentin ${ }^{\mathrm{a}, *}$, Bernard Gomez $^{\mathrm{b}}$, Véronique Daviero-Gomez ${ }^{\mathrm{b}}$, Sylvain Charbonnier $^{\mathrm{c}}$, Patrice Ferchaud ${ }^{\mathrm{d}}$, Alexandre G. Kirejtshuk ${ }^{\mathrm{e}}$, Alexis Licht ${ }^{\mathrm{a}}$, Didier Néraudeau, Romain Vullo ${ }^{f}$ and Géraldine Garcia ${ }^{a}$

\footnotetext{
a IPHEP, UMR7262 CNRS, Université de Poitiers, 6 rue M. Brunet, 86073 Poitiers France

b Laboratoire de Géologie, UMR 5276 CNRS, Université Lyon 1 (Claude Bernard), Campus La Doua, Bât. Géode, 43 boulevard du 11 Novembre 1918, 69622 Villeurbanne, France

${ }^{c}$ Centre de Recherche sur la Paléobiodiversité et les Paléoenvironnements UMR7207 CNRS, UPMC, Université Paris 6 et Muséum national d'Histoire naturelle, 8 rue Buffon, 75005 Paris, France

d 41 rue des Genêts 86280 Saint Benoit, France

e Zoological Institute of Russian Academy of Sciences, Universitetskaya nab., 1, 199034 St. Petersbug, Russia and Entomologie, UMR 5202 CNRS, Muséum national d'Histoire naturelle, 45, rue Buffon, 75005 Paris, France

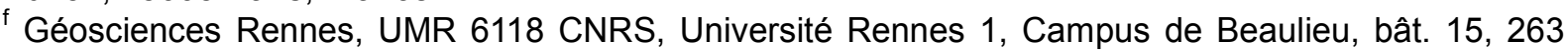
avenue du Général Leclerc, 35042 Rennes, France

* Corresponding author

E-mail address: xavier.valentin@univ-poitiers.fr
}

\section{ABSTRACT}

Two fossil localities are reported on the "LGV SEA" railroad from the lower Cenomanian of Jaunay-Clan (JC), near Poitiers, western France. The laminated mudstones yielded plant fossils including ferns (Cladophlebis, Osmundophyllum, Ruffordia goeppertii, Sphenopteris), conifers (Brachyphyllum, Dammarophyllum, Pagiophyllum), and terrestrial and aquatic freshwater angiosperms (Eucalyptolaurus depreii, Ploufolia). They are associated with a coleopteran insect that shows systematic affinities to the modern subfamily Chrysomelinae (Chrysomelidae). This assemblage suggests connections with arborescent vegetation growing in calm freshwater environment. Brackish to marine invertebrates also occur and include a dakoticancroid crab (Brachyura, Podotremata, Dakoticancroidea) and a few bivalves (Brachidontes). They suggest brackish episodes during pond sedimentation in a coastal environment. Lastly, vertebrates are represented by an isolated feather.

\section{RESUME}

Deux nouvelles localités fossiles sont découvertes sur la voie de chemin de fer de la "LGV SEA" dans le Cénomanien inférieur de Jaunay-Clan (JC), près de Poitiers, ouest de la France. Des dépôts argileux finement laminés ont livré un grand nombre de plantes fossiles comprenant des fougères (Cladophlebis, Osmundophyllum, Ruffordia goeppertii, Sphenopteris), des conifères (Brachyphyllum, Dammarophyllum, Pagiophyllum), des angiospermes terrestres et aquatiques (Eucalyptolaurus depreii, Ploufolia). Ils sont associés à un insecte coléoptère présentant des affinités systématiques avec la sous-famille moderne des Chrysomelinae (Chrysomelidae). Cet assemblage suggère des connections avec une végétation arborescente poussant dans un environnement dulçaquicole calme. Des invertébrés saumâtres à marins ont été trouvés également et incluent un crabe de type dakoticancroïde (Brachyura, Podotremata, Dakoticancroidea), et quelques bivalves (Brachidontes). Ils suggèrent des épisodes saumâtres durant la sédimentation dans un milieu paralique en position côtière/lagunaire. Enfin, les vertébrés sont représentés par une plume isolée. 
Key-words: plant fossils, invertebrates, freshwater environment, lower Cenomanian, western France

Mots-Clés: plantes fossiles, invertébrés, environnement d'eau douce, Cénomanien inférieur, Ouest de la France

\section{Introduction}

In the last decade, several fossil plant localities have been reported from the Cretaceous of western France (Gomez et al., 2004, 2008; Néraudeau et al., 2002, $2003,2005,2008,2009,2012,2013)$. By contrast, the department of Vienne (86) is well-known in the south-western part of the Paris basin for marine fossil assemblages, especially from the Upper Jurassic deposits and the Cenomanian "Green Sandstones" (Mathieu, 1968). Albian-Cenomanian continental, estuarine and paralic sediments have limited exposures (Joubert, 1980).

During the years 2012 and 2013, the digging works for the railroad "LGV SEA" between Tours and Bordeaux have exposed numerous Cenomanian continental, and particularly estuarine and paralic deposits. Repeated field prospections have been led by XV and PF following a license of research established by private developers. Two new localities, Ormeau-Saint-Denis (JCO) and Bergère (JCB), were collected for fossil remains nearby the village of Jaunay-Clan $15 \mathrm{~km}$ from Poitiers (Fig. 1). They yielded well-preserved, abundant plant assemblages associated with crustaceans and insects. We report and describe for the first time these Cenomanian animal and plant assemblages.

\section{Geological context}

The lower Cenomanian succession has been thoroughly described in the studied area (Le Touzé de Longuemar, 1870; Joubert, 1980; Alvarez, 1980). Briefly, lower Cenomanian deposits overlay a paleokarst surface developed over a CallovianOxfordian limestone platform (Mathieu, 1960). Lowermost beds consist of finely laminated lignitic mudstones that progressively grade to 1 to $10-\mathrm{m}$-thick laminated, unfossiliferous grey silts. They are usually overlaid by 10 to $30-\mathrm{m}$-thick glauconious sands with rare decimeter-thick carbonate beds (also called the Furigny sandstones; Alvarez, 1980). The 10 uppermost meters of the lower Cenomanian succession are glauconious sandstones commonly intercalated with decimeter-thick beds of laminated grey marls (Joubert, 1980).

At the Ormeau-Saint-Denis locality (JCO), the paleokarst surface is covered by a decimeter-thick bed of bivalve-bearing mudstones (Fig. 2); the uppermost layers of these mudstones bear abundant fossil plant remains. This bed is overlaid by a lag of coarse clasts, including mudclasts and reworked pisolites that precede the lower Cenomanian succession, first decimeters of which are also rich in fossil remains (Figs. 1 and 2). At the Bergère locality (JCB), the paleokarst surface displays a partlypreserved paleosol profile resembling those observed on the Jurassic rings of the Paris Basin (Thiry et al., 2006), consisting of 20 to $60-\mathrm{cm}$-thick ochreous clay overlaid by a $20-\mathrm{cm}$-thick ferruginous crust made of iron pisolites. The profile is overlaid by a 1-m-thick and 10-m-wide pocket of green-gray mudstones that fills a small depression of the paleokarst surface (Fig. 1). These mudstones display poorly preserved laminations rich in plant debris and vertical millimeter-thick root traces. They are overlaid by a lag of coarse clasts that precedes the lower Cenomanian succession and are stratigraphically correlated with the conglomeratic lag observed at Ormeau-Saint-Denis locality. Accordingly, the lowermost mudstone beds of both sites are interpreted as deposited in a probably alternating freshwater and brackish, pond-like environments at the beginning of the Cenomanian transgression.

\section{Material and Methods}

We prospected exposures along the "LGV SEA" railroad during the week-ends following an agreement with the companies LISEA and COSEA (VINCl group) (Fig. 2a). In particular, we ran two large excavations of 120 square meters each, digging 
2.5 meters in depth with twenty volunteers, at Ormeau-Saint-Denis (JCO) and Bergère (JCB) between May and October 2013 (Fig. 2b and C).

We split apart clayey slabs with knifes to locate fossils and millimetric amber pieces. In JCB, plant fossils were so dense and interbedded that we had to collect large blocks of mudstone and wrapped them with plaster jackets. Wet rock specimens were wrapped in cellophane to limit fast dehydration and broken fossils. More than 400 mudstone specimens with plant fossils have been collected. They are housed in the collections of the University of Poitiers (UP) under the numbers UPJCO year-number and UP-JCB year-number. Photographs were taken with a Canon EOS 60D coupled to a Canon macrolens EF $100 \mathrm{~mm}$. The beetle and crab specimens were studied using a stereomicroscope Olympus SCX9.

\section{Paleobotany and paleontology}

4.1. Plants.

Ferns are the less abundant plant remains. Fragments of three sterile pinnae consist of a narrow rachis bearing pinnules alternately on both sides (Fig. 3a-e). Pinnules are triangular to lanceolate. The pinnules are attached by a broad base, with an acroscopic sinus and basiscopic decurrent margin. The margin is typically entire or lobed basally at the proximal and distal part of pinnae (Fig. 3a-c). Pinnules are slightly toothed half distally (Fig. $3 a, b, d$ and e). One- to three-time-dichotomized secondary veins arise from the midvein, except in lobes that show no midvein (Fig. $3 a-c)$. Veins end into the margin and into the teeth when they are developed (Fig. 3a, b, d and e). Similar sterile (e.g., Cladophlebis, Osmundophyllum) and fertile (e.g., Raphaelia) foliage remains have described from the Cretaceous of Europe. Although these specimens closely resemble some species described from the Cenomanian of Czech Republic, such as Raphaelia woldřichi (Mařík, 1901; Velenovský and Viniklář, 1927), they are herein attributed to Cladophlebis because of the lack of fertile parts. Although many Cladophlebis species were proved to belong to Osmundaceae (van Konijnenburg-van Cittert, 2002), the present sterile material is only temporally assigned to this fern family until further evidence. A second fern type consists of several specimens. They usually show only sterile isolated pinnules, but one specimen bears two clusters of sporangia at the base of an entire oblong pinnule lamina (Fig. 3h). The base is lengthily tapered toward the rachis or petiole, and the apex is obtuse. Three- to four-time-dichotomized secondary veins arise from the midvein and end at the margin. These specimens much resemble Osmunda regalis in shape and venation pattern of pinnules. Osmundophyllum cretaceum from the Bohemian Cenomanian is also quite similar (Velenovský, 1889; Frič and Bayer, 1901), but both the latter and the living royal fern usually show non-tapered pinnules with cordate bases, except for some apical pinnules. Cladophlebis and Raphaelia, or the Triassic-Jurassic Todites and Osmundopsis, show pinnules with a large insertion onto the rachis (e.g., Harris, 1961; van Konijenburg-van Cittert, 1996). Our specimens are temporally ascribed to the genus Osmundophyllum. A third fern type consists of a single specimen showing a bi-pinnate fragment of frond (Fig. 3f). The rachises are very narrow, and bear elongate lanceolate pinnules. Pinnules are attached by a narrow base. The margin is entire. Venation is not observed. It resembles some schizaeaceous Anemia-like ferns, especially the Lower Cretaceous Ruffordia goeppertii (e.g., Sender et al., 2005). It is noteworthy that in situ Anemialike spores have been described in Anemia cf. fremontii from the Cenomanian of Horoušany, Czech Republic (Pátová and Kvaček, 2006). Pátová and Kvaček (2006) compared the associated sterile fronds with Onychiopsis capsulifera (Velenovský, 1888; Frič and Bayer, 1901), which questions the latter generic attribution since the genus Onychiopsis belongs otherwise to the Dicksoniaceae (e.g., Friis and Pedersen, 1990). A fourth fern type also consists of a single specimen with two or three broadly lobed pinnules (Fig. $3 \mathrm{~g}$ ). The pinnules are attached by a narrow base on the rachis. The venation consists of several-time-dichotomized veins. It is attributed to the genus Sphenopteris based on the narrow base of insertion, the lobed lamina and the several-time dichotomized veins without a midvein. It is of uncertain systematic affinity. 
Conifers are also poorly abundant and diverse. A first type consists of slender shoots showing two or three-branched stems and scale-like leaves (Fig. 4a and c). The leaves are tiny with a short free part, packed against the stem, and spirally arranged. They are ascribed to the genus Brachyphyllum, which representatives belong to several fossil and living conifer families. A second type consists of rare unbranched stems bearing spirally arranged leaves (Fig. 4b) and more abundant isolated leaves (Fig. 4d). In both, the laminar shape is obovate to oblanceolate. The base is lengthily tapered, and the apex is usually obtuse. The veins are equal. They arise parallel from the base. They converge near the apex when the lamina narrowed and end at or very near the margin. In the mid Cretaceous broad leaved conifers are included in several genera: Dammarophyllum, Dammarites, Lindleycladus, Nageiopsis, Nageiopteris, and Podozamites. Dammarites differs in showing longer and wider linear, sessile leaves that arise from short tuberous stems, and end by acute apices (Hluštík, 1976; Kvaček, 2003). Nageiopsis differs in having usually decurrent leaf bases and parallel veins that run straight into the apex margin without converging (Kvaček, 2003). Lindleycladus differs in having lanceolate leaves, strongly contracted but scarcely petiolate bases, distal ends tapering to blunt points, and outer veins ending by meeting margins at a small angle (Harris, 1979). Nageiopteris differs in having often axes with areas of close spirally arranged scars reminiscent of winter bud scales in extant conifers, and the veins do not converge and unite at the leaf apex Fontaine (1889, cited in Seward, 1919; Cantrill, 1991). Podozamites differs in showing contracted leaf bases, and veins spread proximally but were parallel for most of the leaf length (Seward, 1919; Cantrill, 1991). Thus, both leaved axes and isolated leaves are ascribed to the so far monospecific genus Dammarophyllum based on the leaf shape and venation pattern (Kvaček, 2003). A third type consists of a single, ill-preserved specimen (Fig. 4e). It shows an unbranched stem bearing spirally arranged, small awl-shaped leaves. The leaves show a long free part, a convex abaxial surface much larger than a concave adaxial surface, and a very acute apex. It is temporarily ascribed to the genus Pagiophyllum (Harris, 1979).

Angiosperms are by far the most abundant and diversified. All specimens are isolated leaves. Among them, several simple and petiole leaves show narrow, elongate, and lanceolate to linear laminas (Figs. 5a and b). The margin is entire. The primary venation is pinnate, and the secondary venation is brochidodromous, merging into bilateral intramarginal veins. Intersecondary veins branch exmedially. They correspond to Eucalyptolaurus depreii, also described from the AlbianCenomanian of Charente-Maritime (Coiffard et al., 2009). Elliptic to obovate nanophylls show eccentric peltate attachment from which arises one medial primary vein and lateral veins that dichotomize several times before merging into an intramarginal vein (Fig. 5e). The margin is slightly undulated, and bears small glands. They correspond to Ploufolia erected based on specimens from the Albian of Spain and Portugal (Sender et al., 2010). Lastly, many leaf forms consist of a single specimen (Figs. 5c, d, f and g). Interestingly, angiosperm leaves show frequent and diverse insect bites.

\subsection{Molluscs.}

Molluscs are rare, and the three forms distinguished below are represented by a single or a few specimens from the JCO locality. Costulated mytiloid specimens belong to the genus Brachidontes (Fig. 6c). Similar specimens are found in clayey plant beds from the Cenomanian of Arizona, USA (Kirkland, 1996) and Anjou, France (Néraudeau et al., 2013). Kirkland (1996) and Néraudeau et al. (2013) suggested that Brachidontes-bearing facies correspond to brackish coastal environments. A smooth, very asymmetrical and posteriorly very elongated shell is not identified, but it belongs more likely to marine coastal families, such as Mactridae, Pandoridae, and Tellinidae than to freshwater family such as Unionidae (Néraudeau et al., 2013). Thus, the shell shows a very oblique posterior truncation and a ventral margin shorter than the dorsal margin, an outline unknown for unionids and uncommon, but present, in some marine coastal bivalves. These features of shell morphology mostly 
resemble the living Pandoridae. However, "typical" Pandora species first appeared during the Eocene and the Cenomanian representatives may have belonged rather to Mactridae or Tellinidae, which are known from the Cretaceous, though many species show posteriorly elongated shell without the same shell posterior truncation. A third and last form of subcircular shell appears closely related to the marine genus Protocardia. The three bivalve species of Jaunay-Clan are also associated in the lower Cenomanian of Anjou, France (Néraudeau et al., 2013).

\subsection{Arthropods.}

\subsubsection{Crustaceans.}

Decapod crustaceans are represented in JCO section by one well-preserved specimen of brachyuran crab (Brachyura, Podotremata) with the carapace still being attached to the pereiopods (Fig. 6a and b). The carapace is relatively short, and the frontal margin shows wide orbits. The ventral side (Fig. 6b) shows the anterior thoracic sternites 1-4, suggesting that it corresponds to a male crab. The first left pereiopod bears a slender and robust chela. Despite these characters, the crab affinities are difficult to ascertain. It is close to the Dakoticancroidea that includes two fossil families: Dakoticancridae and Ibericancridae. Interestingly, Dakoticancridae are restricted to the Late Cretaceous of North America and northeast Mexico (Rathbun, 1917, 1923; Bishop, 1988; Vega and Feldmann, 1991), and Ibericancridae are known from the Late Cretaceous of Spain (Artal et al., 2008) and of North America (Feldmann et al., 2013). Dakoticancroid crabs are only known from marine environments.

\subsubsection{Insects.}

The single specimen from JCO (Fig. 7) consists of part and counterpart. It resembles the recent representatives of the subfamily Chrysomelinae (Chrysomelidae) in the following features: the outlines of all sclerites including elytra; the narrowly to moderately separated metacoxae; the diffuse and sparse coarse punctuation on the elytra; the procoxae moderately separated and somewhat transverse; the large pronotum slightly narrowing anteriorly but not or scarcely posteriorly; the comparatively long and stout femora and longer ventrite 1 . Although the above list of similarities between the specimen examined and other members of chrysomelids is not enough to ground a more precise identification, the subfamily assignation is actually reliable. In addition, two isolated dragonfly wings have been recently found and are currently under study.

\subsection{Vertebrates.}

A single, relatively poorly preserved, isolated feather has been found (Fig. 6d). Its preserved length is $21.5 \mathrm{~mm}$. The calamus cannot be observed. The rachis is visible in the proximal part and becomes very thin and narrow distally. The feather displays pennaceous barbs organised in symmetrical closed vanes. The angle between the rachis and barbs is around 30 degrees. The barb density on each side of the rachis is 2 per $\mathrm{mm}$. Barbules cannot be observed. This specimen can be interpreted as a body feather of an avian or non-avian theropod. Interestingly, a similar feather has been recently described from the contemporaneous beds of another plant-bearing lagerstätte of western France (Vullo et al., 2013).

\subsection{Ichnology}

Two types of trace fossils have been found in the plant-bearing clayey beds of Jaunay-Clay. The first, relatively common, trace type corresponds to meandering, smooth, non-branching burrows generally less than $30 \mathrm{~mm}$ in length. Their maximum width is about $4 \mathrm{~mm}$, and both extremities become progressively thinner. They can be assigned to Cochlichnus anguineus, a widespread ichnospecies known for instance from the Wealden strata of England (Goldring et al., 2005). Several Cochlichnus traces are often present on the same plate, sometimes converging on a larger, poorly defined trace fossil (ichnogenus cf. Lockeia) (Fig. 6e). 
The second trace fossil is represented by a single indeterminate trackway (less than $10 \mathrm{~mm}$ in width), probably made by a small invertebrate. It shows a median, longitudinal groove flanked on both sides by a series of short (less than $3 \mathrm{~mm}$ ), regularly arranged, perpendicular marks (Fig. 6f).

\section{Discussion}

Plant assemblages of Jaunay-Clan consist of a mixture of few ferns and conifers with very abundant and diverse angiosperms. The family Osmundaceae is represented by the genera Cladophlebis and Osmundophyllum, while the family Schizaeaceae includes Ruffordia goeppertii. The conifers are of uncertain systematic affinities including the genus Dammarophyllum that belongs to either Araucariaceae or Podocarpaceae based on the Florin ring present around the stomatal pit. Angiosperms include probable Nymphaeales (Ploufolia), Magnoliids (Eucalyptolaurus depreii) and diverse Eudicots.

The fossil plant assemblage mostly consists of isolated leaves with the petioles showing basal, slightly widened, insertion scars. There are a few leafy stems of conifers (Brachyphyllum, Pagiophyllum and Dammarophyllum) that still have leaves in connection to the stems. However, the leaves and leafy stems were probably produced by natural loss after normal senescence. Insect leaf bites are frequent especially in angiosperm leaves. However, wounds usually show thickened rims around that indicate that plant parts healed and survived for a while. Insect leaf bites are diverse, suggesting they were produced by various insect types (Chapuis, 1874). Based on the diversity, the completeness and the absence of abrasion, the transport was probably short and/or calm. Parautochthony is probable for the fossil plants, but the occurrence of numerous Nymphaeales Ploufolia remains suggests a freshwater episode in a pond-like environment. The presence of brackish to marine molluscs and a specimen of Dakoticancroid crab below and above the Nympheales beds respectively indicate that the freshwater episode has interrupted a brackish sedimentation trend in a paralic, coastal basin (see interpretation on Fig. 2b).

The single leaf-beetle collected displays the typical characters of the family Chrysomelidae usually considered as advanced. Data published about fossils of this family are quite ambiguous. Although some chrysomelids were reported from the Triassic and Jurassic (Heer, 1877; Santiago-Blay, 1994), most of them do not quite resemble cucujiformians (infraorder Cucujiformia). During a long time the subfamily Protoscelinae from the Upper Jurassic of Karatau (Karabastau Formation, Kazakhstan) was regarded as the earliest chrysomelids. However, Legalov (2013) showed that this subfamily must be included in the superfamily Curculionoidea (Anthribidae Billberg, 1820). Besides, Tarsomegamerus was initially described as a leaf beetle from the Middle Jurassic of Daohugou (Jiulongshan Formation Inner Mongolia, China: Zhang, 2005), but it was later transferred to the infraorder Elateriformia (Kirejtshuk et al. 2010a; Kirejtshuk and Azar, 2013b: Eulichadidae Crowson, 1973). Nevertheless, the family Chrysomelidae could appear as one of the earliest cucujiformian groups (Kirejtshuk, 1994). Wolf-Schwenninger and Schawaller (2007) ascribed to the subfamily Eumolpinae leaf beetle from the Lower Cretaceous of Santana (Crato Formation, Brazil). Kirejtshuk et al. (2010b) reported one chrysomeloid group probably related to Aulacoscelinae and beetles like Hispinae from the Lower Cretaceous of Chaomidian (Yixian Formation, Liaoning Province, China). More detailed review of the fossil record is given by Kirejtshuk and Ponomarenko (2013a). Thus, it is likely the finding of a member of subfamily Chrysomelinae sensu stricto. Based on trophic interactions of living members of this subfamily, this fossil species could have feed on angiosperms rather than on gymnosperms.

More new localities were collected during field prospections in marine Cenomanian sediments close to the villages of Saint-Léger la Pallu (close to Marigny-Brizay) and Scorbé-Clairvaux. They contain diverse fossil vertebrate remains including selachians, bony fishes and reptiles (chelonians, crocodyliforms, elasmosaurid plesiosaurs, ornithocheirid pterosaurs, the snake Simoliophis) and sometimes a few small amber drops. They are currently under more detailed study. 
The new localities from the lower Cenomanian of Jaunay-Clan offer new perspectives on the diversity and evolution of ecosystems in Europe, especially concerning angiosperms and arthropods during the Cretaceous.

\section{Acknowledgements}

This work was conducted under an agreement for paleontological researches signed between LISEA and COSEA (VINCI group) and the PALAIOS society represented by X. Valentin and approved by B. Godinot and H. Tricot in June 2012. We thank C. Macary, M. Leroy and B. Massol for authorizations and C. Sandre, P. Stigliani and J. Vincent of the administrative team for support management. We also thank P. Chadeyron, M. Lafaurie and V. Marquis for support assistance and P. Bégou, E.Hébrant and P. Brocheriou for excavation management. Financial supports were also provided by the CG of Vienne, le Pays Chauvinois and the area of Valdivienne. We especially thank the local officials: Senator A. Fouché, the mayors R. Laurendeau and $M$. Bigeau and the comity of $R$. Benoist and $P$. Bastier. We warmly thank $F$. Auvray, M. Barkat, P. Bastier, R. and J. Benoist, G. Bertrand, D. Berthé, E. Blandin, R. Bouet, T. Capillon, H. Châtelier, T. Coillot, G. Cretin, S. and E. Dépré, J. Drochon, D. Duchène, P. Frey, A. Gris, C. Gros, B. Guevel, L. Haise, J.F. Hilairet, A. Kociuba, P. Lacroix, V. Lazzari, F. Lapalu, A. Lemaitre,. Mathé, P. Paquereau, S. Pecot, M. and J.-C. Petelaud, M. Pouyollon, F. Robin, J.-M. Terrasson, C. and V. Texier, G. Thiery, D. Tornais, S. Tortora; N Trassard, O. Vérité and A. Vilaneau for prospections and works in the fields. We thank G. Breton, M. Daccordi (Museo Civico di Storia Naturale, Verona), P. Godefroit (IRSNB), A. Nel (MNHN) and A.G. Moseyko (Zoological Institute of the Russian Academy of Sciences) for scientific discussions. P.A. Kirejtshuk drew the beetle specimen. We are most grateful to A. Brunellière (UP) and S. Riffaut (UP) for technical support.

\section{References}

Alvarez, P., 1980. L'Oxfordien, le Cénomanien et le Turonien au NW de Poitiers (Vienne). Stratigraphie, sédimentologie, cartographie et hydrogéologie, Ph.D. thesis, Université de Poitiers, $127 \mathrm{p}$.

Artal, P., Guinot, D., van Bakel, B., Castillo J., 2008. Ibericancridae, a new dakoticancroid family (Decapoda, Brachyura, Podotremata) from the upper Campanian (Upper Cretaceous) of Spain. Zootaxa 1907, 1-27.

Billberg, G.J., 1820. Enumeratio Insectorum in Museo Billberg. Gadel, Stockholm, $138 \mathrm{p}$.

Bishop, G.A., 1988. A new crab, Seorsus wadei, from the Late Cretaceous Coon Creek Formation, Union County, Mississippi. Proc. Biol. Soc. Wash. 101, 72-78.

Cantrill, D.J., 1991. Broad leafed coniferous foliage from the Lower Cretaceous Otway Group, southeastern Australia. Alcheringa 15, 177-190.

Chapuis, F., 1874. Familles des phytophages. In: Laccordaire, J.T. (Ed.), Histoire naturelle des insectes, Genera des Coléoptères. Librairie encyclopédique de Roret, Paris Tome 10, 455 p. + iv.

Coiffard, C., Gomez, B., Thiébaut, M., Kvaček, J., Thévenard, F., Néraudeau, D., 2009. Eucalyptolaurus depreii, gen. et sp. nov., intramarginal veined Lauraceae leaves from the Albian-Cenomanian of Charente-Maritime (Western France). Palaeontology, 52, 323-336.

Crowson, R.A., 1973. On a new superfamily Artematopoidea of polyphagan beetles, with the definition of two new fossil genera from the Baltic amber. J. Nat. Hist. 7(2), 225-238.

Feldmann, R.M., Schweitzer, C.E., Baltzly, L.M, Bennett, O.A., Jones, A.R., Mathias, F.F., Weaver, K.L., Yost, S.L., 2013. New and previously known decapod crustaceans from the Late Cretaceous of New Jersey and Delaware, USA. Bull. Mizunami Fossil Mus. 39, 7-37.

Fontaine, W.M., 1889. The Potomac or younger Mesozoic Flora. U. S. Geol. Surv., Monogr. 15, 1-377. 
Frič, A., Bayer, E., 1901. Studien im Gebiete der Böhmischen Kreideformation. Perucer Schichten. Archiv der Naturwissenschaftliche Landesdurchforschung von Böhmen 11, 1-184.

Friis, E.M., Pedersen, K.R., 1990. Structure of the Lower Cretaceous fern Onychiopsis psilotoides from Bornholm, Denmark. Rev. Palaeobot. Palynol. 66, 47-63.

Goldring, R., Pollard, J.E., Radley, J.D., 2005. Trace fossils and pseudofossils from the Wealden strata (non-marine Lower Cretaceous) of southern England. Cret. Res. 26, 665-685.

Gomez, B., Daviero-Gomez, V., Perrichot, V., Thévenard, F., Coiffard, C., Philippe, M., Néraudeau, D., 2004. Assemblages floristiques de l'Albien-Cénomanien de Charente-Maritime (SO France). Ann. Paléont. 90, 147-159.

Gomez, B., Coiffard, C., Dépré, E., Daviero-Gomez, V., Néraudeau, D., 2008. Diversity and histology of a plant litter bed from the Cenomanian of ArchingeayLes Nouillers (southwestern France). C.R. Palevol 7, 135-144.

Harris, T.M., 1961. The Yorkshire Jurassic flora, I. Thallophyta-Pteridophyta. British Museum (Natural History), London, 212 p.

Heer, O., 1877. Vorweltliche Flora der Schweitz. Flora Fossilis Helvetiae. Verlag von J. Wurster and Co., Zürich, 182 p.

Hluštík, A., 1976. Contribution to the systematic and leaf anatomy of the genus Dammarites Presl in Sternberg. Sborník Národního Muzea v Praze, Rada B: Prírodní Vědy 30, 49-70.

Joubert, J.M., 1980. Le Cénomanien des départements de la Vienne et des DeuxSèvres. Géologie et hydrogéologie. Ph.D. thesis, Université de Poitiers, 186 p. (inédit)

Kirejtshuk, A.G., 1994. Sistema, evolutzia obraza zhisni i filogeniya otryada zhukov (Coleoptera). [System, evolution of the mode of life and phylogeny of the order Coleoptera. I]. Entomologicheskoye Obozrenie 73(2), 266-288 (in Russian).

Kirejtshuk A.G., Chang, H., Ren, D., Chung Kun, S. 2010a. Family Lasiosynidae n. fam., new palaeoendemic Mesozoic family from the infraorder Elateriformia (Coleoptera: Polyphaga). Ann. Soc. Entomol. Fr. Nouvelle Série 46 (1-2), 67-87.

Kirejtshuk, A.G., Ponomarenko, A.G., Prokin, A.A., Chang, H., Nikolajev, G.V., Ren, D., 2010b. Current knowledge on Mesozoic Coleoptera from Daohugou and Liaoning (North East China). Acta Geol. Sin. 84(4), 783-792.

Kirejtshuk, A. G., Ponomarenko, A. G. 2013a. Catalogue of fossil Coleoptera. Beetles (Coleoptera) and Coleopterologists. Zoological Institute of the Russian Academy of Sciences, St. Petersburg. Updated March 2012. [updated at http://www.zin.ru/Animalia/Coleoptera/eng/paleosys.htm, accessed December 2013].

Kirejtshuk, A.G., Azar, D., 2013b. Current knowledge of Coleoptera (Insecta) from the Lower Cretaceous Lebanese amber and taxonomical notes for some Mesozoic groups. Terr. Arthropod. Rev. 6(1-2), 103-134.

Kirkland, J.I., 1996. Paleontology of the Greenhorn Cyclothem (Cretaceous, Late Cenomanian to Middle Turonian) at Black Mesa, Northeastern Arizona. New Mexico Mus. Natl. Hist. Nat. Sci. Bull. 9, 1-131.

van Konijnenburg-van Cittert, J.H.A., 1996. Two Osmundopsis species and their sterile foliage from the Middle Jurassic of Yorkshire. Palaeontology 39, 719-731.

van Konijnenburg-van Cittert, J.H.A., 2002. Ecology of some Late Triassic to Early Cretaceous ferns in Eurasia. Rev. Palaeobot. Palynol. 119, 113-124.

Kvaček, J., 2003. Foliage of a broad leaves conifer Dammarophyllum from the Cenomanian of Bohemia. Časopis Národního muzea, Řada prírodovědná 172, 13-20.

Legalov, A.A., 2013. Jbzor semeystva Anthribidae (Coleoptera) iz yury Karatau. Podsemeystvo Protoscelinae. Rod Protoscelis Medvedev [Review of the Family Anthribidae (Coleoptera) from the Jurassic of Karatau: Subfamily Protoscelinae. Genus Protoscelis Medvedev]. Paleontologicheskiy Zhurnal 3, 57-65 (in Russian). 
Le Touzé de Longuemar, M.A., 1870. Etudes géologiques et agronomiques sur le département de la Vienne, A. Dupré, Poitiers, 496 p.

Mařík, V., 1901. Příspěvek k floře českého cenomanu. Rozpr. Čes. Akad. Cís. Fr. Jos. Věd, Sloves. Um. (tř. math.-prírod.) 10, 1-16.

Mathieu, G., 1960. Pénétration des sédiments du Cénomanien dans le karst jurassique du Poitou. C. R. Acad. Sci. Paris 251, 755-757.

Mathieu, G., 1968. Itinéraire d'excursion géologique à Saint-Georges, Beaumont, Lencloître, Mirebeau, Thénezay, Le Terrier-du-Fouillou, Vasles, Poitiers. Norois 60, 522-532.

Néraudeau, D., Perrichot, V., Dejax, J., Masure, E., Nel, A., Philippe, M., Moreau, P., Guillocheau, F., Guyot, T., 2002. Un nouveau gisement à ambre insectifère et à végétaux (Albien terminal probable): Archingeay (Charente-Maritime, France). Geobios 35, 233-240.

Néraudeau, D., Allain, R., Perrichot, V., Videt, B., de Broin, F., Guillocheau, F., Philippe, M., Rage, J.-C., Vullo, R., 2003. Découverte d'un dépôt paralique à bois fossiles, ambre insectifère et restes d'Iguanodontidae (Dinosauria, Ornithopoda) dans le Cénomanien inférieur de Fouras (Charente-Maritime, sud-ouest de la France). C. R. Palevol 2, 221-230.

Néraudeau, D., Vullo, R., Gomez, B., Perrichot, V., Videt, B., 2005. Stratigraphie et Paléontologie (plantes, vertébrés) de la série paralique Albien terminalCénomanien basal de Tonnay-Charente (Charente-Maritime, France). C. R. Palevol 4, 79-93.

Néraudeau, D., Perrichot, V., Colin, J.-P., Girard, V., Gomez, B., Guillocheau, F., Masure, E., Peyrot, D., Tostain, F., Videt, B., Vullo, R., 2008. A new amber deposit from the Cretaceous (uppermost Albian-lowermost Cenomanian) of SW France, Cret. Res. 29, 925-929.

Néraudeau, D., Vullo, R., Gomez, B., Girard, V., Lak, M., Videt, B., Dépré, E., Perrichot, V., 2009. Amber, plants and vertebrate fossils from the Lower Cenomanian paralic facies of Aix Island (Charente-Maritime, SW France), Geodiversitas 31, 13-27.

Néraudeau, D., Allain, R., Ballèvre, M., Batten, D.J., Buffetaut, E., Colin, J.-P., Dabard, M.-P., Daviero-Gomez, V., El Albani, A., Gomez, B., Grosheny, D., Le Loeuff, J., Leprince, A., Martín-Closas, C., Masure, E., Mazin, J.-M., Philippe, M., Pouech, J., Tong, H., Tournepiche, J.-F., R. Vullo, 2012. The HauterivianBarremian lignitic bone bed of Angeac (Charente, south-west France): stratigraphical, palaeobiological and palaeogeographical implications. Cret. Res. $37,1-14$.

Néraudeau, D., Redois, F., Ballèvre, M., Duplessis, B., Girard, V., Gomez, B., Daviero-Gomez, V., Melliere, B., Perrichot, V., 2013. L'ambre cénomanien d'Anjou : stratigraphie et paléontologie des carrières du Brouillard et de Hucheloup (Ecouflant, Maine-et-Loire), Ann. Paléont. 99, 361-374.

Pátová, R., Kvaček, J., 2006. Report on ferns of the Bohemian Cenomanian and their spores in situ. Acta Universitatis Carolinae - Geologia 43, 91-94.

Rathbun, M.J., 1917. New species of South Dakota Cretaceous crabs. Proc. U. S. Nat. Mus. Natl. 52, 385-391.

Rathbun, M.J., 1923. Decapod crustaceans from the Upper Cretaceous of North Carolina. North Carolina Geol. Econ. Survey 5, 403-408.

Santiago-Blay J.A., 1994. Paleontology of leaf beetles. In: Jolivet P.H. \& Pipitpiere (eds.): Novel aspects of the biology of Chrysomelidae. Kluwer Academic Publishers, 1-68.

Sender, L.M., Diez, J.B., Ferrer, J., Pons, D., Rubio, C., 2005. Preliminary data on a new Albian flora from the Valle del Río Martín, Teruel, Spain. Cretaceous Research 26, 898-905.

Sender, L.M., Gomez, B., Diez, J.B., Coiffard, C., Martín-Closas, C., VillanuevaAmadoz, U., Ferrer, J., 2010. Ploufolia cerciforme gen. et comb. nov.: Aquatic angiosperm leaves from the Upper Albian of north-eastern Spain. Rev. Palaeobot. Palynol. 161, 77-86.

Seward, A.C., 1919. Fossil Plants, volume 4. Cambridge University Press, 
Cambridge, $543 \mathrm{p}$.

Thiry, M., Quesnel, F., Yans, J., Wyns, R., Vergari, A., Thieveniaut, H., SimonCoinçon, R., Ricordel, C., Moreau, M.G., Giot, D., Dupuis, C., Bruxelles, L., Barbarand, J., Baele, J.M., 2006. Continental France and Belgium during the Early Cretaceous: paleoweatherings and paleolandforms. Bull. Soc. Géol. Fr. 177, 155175.

Vega, F.J., Feldmann, R.M., 1991. Fossil crabs (Crustacea, Decapoda) from the Maastrichtian Difunta Group, northeastern Mexico. Ann. Carnegie Mus. 60, 163177.

Velenovský, J., 1888. Die Färne der Böhmischen Kreideformation. Abh. Kaiser.könig. Böhm. Gesell. Wiss. 7, 1-32.

Velenovský, J., 1889. Květena Českého Cenomanu. Rozpr. Král. České Společnosti Nauk. 7, 1-75.

Velenovský, J., Viniklář, L., 1927. Flora Cretacea Bohemiae. II. Rozpr. Stát. Geol. Úst. České Rep. 2, 1-54.

Vullo, R., Néraudeau, D., Dépré, E., 2013. Vertebrate remains from the Cenomanian (Late Cretaceous) plant-bearing Lagerstätte of Puy-Puy (Charente-Maritime, France). Cret. Res. 45, 314-320.

Wolf-Schwenninger, K., Schawaller, W., 2007. Coleoptera: beetles. 338-350. In: Martill, D.M., Bechly, G., Loveridge, R.F. (Eds.), The Crato fossil beds of Brazil: window into an ancient world. Cambridge University Press, $625 \mathrm{p}$.

Zhang, J.-F., 2005. The first find of chrysomelids (Insecta: Coleoptera: Chrysomeloidea) from Callovian-Oxfordian Daohugou biota of China. Geobios, $38,865-871$.

\section{Figure Captions}

Fig. 1. Synthetic logs of Ormeau-Saint-Denis (JCO) and Bergère (JCB) near the village of Jaunay-Clan, showing the first meters of lower Cenomanian overlaying the Oxfordian limestones.

Fig. 1. Logs synthétiques des deux localités Ormeau-Saint-Denis (JCO) et Bergère (JCB) situées près du village de Jaunay-Clan, montrant les premiers mètres du Cénomanien inférieur qui surmontent les calcaires oxfordiens.

Fig. 2. Views of the excavations close to Jaunay-Clan. a-b, Ormeau-Saint-Denis locality (JCO), with detailed log and interpreted palaeoenvironments on subfig. 2; c, Bergère locality (JCB).

Fig. 2. Vues des différents chantiers de fouille près de Jaunay-Clan. $a-b$, localité d'Ormeau-Saint-Denis (JCO), avec log détaillé et les paléoenvironnements interprétés sur la sous figure 2 ; c, localité de Bergère (JCB)

Fig. 3. Ferns.

a-e, Cladophlebis sp., a-b, UP-JCO 13-30a et b, pinna with lanceolate triangular pinnae, attached by a broad base on the rachis, with once to thrice dichotomous veins arising from the midvein; c, UP-JCO 13-35, distal part of pinna with oval to rounded pinnae, attached by a broad base on the rachis, with once to thrice dichotomous veins; $d-e$, UP-JCO 13-52a et $b$, pinna with lanceolate pinnules, attached by a broad base on the rachis, with once to thrice dichotomous veins arising from the midvein; f, UP-JCO 13-27, Ruffordia goeppertii, frond with several elongate lanceolate pinnules; g, UP-JCO 13-31, Sphenopteris sp., pinna with broadly lobed pinnules, attached by a narrow base on the rachis, with several times dichotomous veins; h, Osmundophyllum sp., UP-JCO 13-59a, complete frond with three to four times dichotomous veins arising from the midvein and at the base of the lamina two clusters of spores. All scale bars are $10 \mathrm{~mm}$.

Fig. 3. Fougères.

a-e, Cladophlebis sp., a-b, UP-JCO 13-30a and b, penne avec pinnules lancéolées triangulaires, insérées par une base large sur le rachis, avec une nervation médiane 
et des nervures dichotomes ramifiées 1 à 3 fois; c, UP-JCO 13-35, partie terminale d'une penne avec pinnules ovales à rondes, insérées par une base large sur le rachis, avec des nervures dichotomes ramifiées 1 à 3 fois; d-e, UP-JCO 13-52a and $b$, penne avec pinnules lancéolées, insérées par une base large sur le rachis, avec une nervation médiane et des nervures dichotomes ramifiées 1 à 3 fois; $f$, UP-JCO 13-27, Ruffordia goeppertii, fronde avec plusieurs pinnules allongées lancéolées; g, UP-JCO 13-31, Sphenopteris sp., penne avec pinnules largement lobées, insérées par une base étroite sur le rachis, avec une nervation plusieurs fois dichotomes; $h$, UP-JCO 13-59a, Osmundophyllum sp., fronde entière avec une nervure médiane d'où partent des nervures 3 à 4 fois dichotomes et à la base du limbe deux "grappes" de spores. Toutes les barres d'échelle font $10 \mathrm{~mm}$.

Fig. 4. Conifers.

a, Brachyphyllum sp., UP-JCO 13-23, shoot several times branched with spirally arranged scale-like leaves; b, Dammarophyllum sp., UP-JCO 13-09a, shoot with spirally-arranged oblanceolate leaves and parallel veins; c, Brachyphyllum sp., detail of 1; d, Dammarophyllum sp., UP-JCO 13-47a, isolated oval obovate leaf showing a long tapered base, parallel veins and an obtuse apex; e, Pagiophyllum sp., UP-JCO 13-08, stem bearing spirally arranged awl shaped leaves with a long free part. Scale bars: $10 \mathrm{~mm}$.

Fig. 4. Conifères.

a, Brachyphyllum sp., UP-JCO 13-23, rameau ramifié plusieurs avec feuilles écailleuses spiralées; b, Dammarophyllum sp., UP-JCO 13-09a, rameau avec feuilles lancéolées spiralées et nervures parallèles; c, Brachyphyllum sp., détail de 1; $d$, Dammarophyllum sp., UP-JCO 13-47a, feuille isolée ovale lancéolée montrant une base longuement atténuée, des nervures parallèles et un apex obtus; e, Pagiophyllum sp., UP-JCO 13-08, tige portant des feuilles spiralées à longue partie libre. Barres d'échelle: $10 \mathrm{~mm}$.

Fig. 5. Angiosperms.

a-b, Eucalyptolaurus sp., UP-JCO 13-54 and UP-JCO 13-55, two lanceolate to linear leaves showing a long tapered base, entire margin with intramarginal vein; c, UPJCO 13-70, Ovate, petiolate leaf, slightly asymmetrical, with decurrent base, obtuse apex, and pinnate venation; d, UP-JCO 13-71, Elliptic to obovate leaf, strongly asymmetrical, with retuse apex; e, Ploufolia sp., UP-JCO 13-90, obovate nanophyll with eccentric peltate attachment, one medial primary vein and lateral veins that dichotomize several times; f, UP-JCO 13-72, Elliptic, petiolate leaf, with asymmetrically decurrent base, retuse apex, and pinnate venation; g, UP-JCO 13-75, Oblong, petiolate leaf, asymmetrically decurrent base, obtuse apex, and pinnate venation. Scale bars: $10 \mathrm{~mm}$.

Fig. 5. Angiospermes.

a-b, Eucalyptolaurus sp., UP-JCO 13-54 et UP-JCO 13-55, deux feuilles lancéolées à linéaires montrant une base longuement atténuée, une marge entière avec une nervure intra-marginale; $\mathrm{c}$, UP-JCO 13-70, feuille pétiolée ovale, légèrement asymétrique, avec une base décurrente, un apex obtus, une nervation pennée; $d$, UP-JCO 13-71, feuille pétiolée, elliptique à obovale, fortement asymétrique, avec un apex rétus; e, Ploufolia sp., UP-JCO 13-90, nanophylle avec une insertion peltée excentrique, une nervure primaire médiane et des nervures latérales qui se dichotomisent plusieurs fois; f, UP-JCO 13-72, feuille pétiolée, elliptique, avec une base décurrente asymétrique, un apex rétus et une nervation pennée; g, UP-JCO 1375 , feuille pétiolée, elliptique, avec une base décurrente asymétrique, un apex obtus et une nervation pennée. Barres d'échelle: $10 \mathrm{~mm}$.

Fig. 6. Crustaceans, bivalves, feather and trace fossils.

$\mathrm{a}-\mathrm{b}$, Brachyuran crab (Dakoticancroidea?), UP-JCO 13-80 a and b, part (a) and counterpart (b) showing ventral side with the anterior thoracic sternites (probable male specimen); c, Mytiloid Bivalve (Brachidontes), UP-JCO 13-110 a (BN12); d, indeterminate theropod feather, UP-JCO 14-02; e, several small meandering traces 
(Cochlichnus anguineus) around a possible bivalve resting trace (cf. Lockeia), UPJCO 13-100; $\mathrm{f}$, indeterminate invertebrate trackway, UP-JCO 13-101. Scale bars: 5 $\mathrm{mm}(4-6)$ and $10 \mathrm{~mm}(1-3)$.

Fig. 6. Crustacés, bivalves, plume et traces fossiles.

$a-b$, Crabe brachyoure (Dakoticancroidea?), UP-JCO 13-80 a et b, empreinte (a) et contre-empreinte (b) montrant la face ventrale avec les sternites thoraciques antérieurs (probable spécimen mâle); c, Bivalve mytiloïde (Brachidontes), UP-JCO 13-110 a (BN12); $d$, plume de théropode indeterminé, UP-JCO 14-02; e, plusieurs petites traces sinueuses (Cochlichnus anguineus) autour d'une trace laissée par un bivalve (cf. Lockeia), UP-JCO 13-100; f, piste d'invertébré indéterminé, UP-JCO 13101. Barres d'échelles : $5 \mathrm{~mm}(4-6)$ et $10 \mathrm{~mm}(1-3)$.

Fig. 7. Coleoptera gen. et sp. (Coleoptera, Chrysomelidae, Chrysomelinae). a, UPJCO 13-32 a, part, b, UP-JCO 13-32 b, counterpart, c, reconstruction. Scale bar: 10 $\mathrm{mm}$.

Fig. 7. Coleoptera gen. et sp. (Coleoptera, Chrysomelidae, Chrysomelinae). a, UPJCO 13-32 a, empreinte b, UP-JCO 13-32 b, contre-empreinte, c, reconstitution. Barre d'échelle : $10 \mathrm{~mm}$. 